\title{
HUBUNGAN ASUPAN KAFEIN DENGAN KALSIUM URIN PADA LAKI-LAKI DEWASA AWAL
}

\author{
Eva Yulia Safitri, Deny Yudi Fitranti* \\ Program Studi Ilmu Gizi Fakultas Kedokteran Universitas Diponegoro \\ J1.Dr.Sutomo No.18, Semarang, Telp (024) 8453708, Email : gizifk@ undip.ac.id
}

\begin{abstract}
Background : Hypercalciuria is one of the risk osteoporosis factor. The lifestyle of high caffeine intake caused an increase in urinary calcium excretion. Caffeine increase levels of urinary calcium excretion through decreased reabsorbency of calcium in the kidney.

Objective : The aim of the study is to determine correlations of caffeine intake to urinary calcium in young adult male. Methods : Cross sectional study design with 46 young adult male, aged between 18-24 years, who was selected by consecutive sampling. Nutrient intake data obtained through interviews using a food recall 24 hours questionare during 4 days, data collected included protein intake, phosphorus intake, calcium intake and sodium intake. The levels of urinary calcium was measured with ortho-cresolphtalein complexone (OCPC) method on the day-5 after food 24 hours recall interviews. The bivariat analysis was using Pearson Product Moment or rank Spearman test.

Results : There are 2,2\% subjects who had high levels of urinary calcium. The mean of caffeine intake was 95,74 \pm 101,67. There are no correlations of caffeine intake to urinary calcium $(p>0,05)$. However, there was significant correlation between protein intake $(r=0,420)$ and phosphorus intake $(r=0,356)$ to urinary calcium $(p<0,05)$.

Conclusions : There are no correlations of caffeine intake to urinary calcium in young adult male.

Keywords : urinary calcium levels, caffeine intake, phosphorus intake, protein intake, calcium intake, sodium intake
\end{abstract}

\section{ABSTRAK}

Latar Belakang: Hiperkalsiuria merupakan salah satu faktor risiko terjadinya osteoporosis. Gaya hidup konsumsi tinggi kafein dapat menjadi faktor pemicu tingginya pengeluran kalsium dalam urin. Kafein dapat meningkatkan kadar kalsium dalam urin melalui penurunan reabsorbsi kalsium di ginjal.

Tujuan: Mengetahui hubungan asupan kafein dengan kalsium urin pada laki-laki dewasa awal

Metode: Penelitian ini termasuk penelitian observasional dengan desain crossesctional. Sebanyak 46 laki-laki dewasa menjadi subjek dalam penelitian ini dan diperoleh melalui consecutive sampling. Data riwayat asupan makanan diperoleh melalui wawancara menggunakan food recall 24 jam selama 4 hari yang meliputi asupan kafein, asupan protein, asupan fosfor, asupan kalsium dan asupan natrium. Kadar kalsium urin diukur dengan metode orthocresolphtalein complexone (OCPC) pada hari ke-5 setelah dilakukan wawancara food recall 24 jam. Analisis bivariat menggunakan uji Pearson Product Moment atau uji Rank Spearman.

Hasil: Sebanyak 2,2\% subjek memiliki kadar kalsium urin tinggi. Rata-rata asupan kafein subjek 95,74 $\pm 101,67$. Menurut hasil analisis, asupan kafein tidak memiliki hubungan dengan kadar kalsium urin (p>0,05). Namun, asupan protein $(r=0,420)$ dan asupan fosfor $(r=0,356)$ memiliki hubungan bermakna dengan kadar kalsium urin $(p<0,05)$.

Kesimpulan: Asupan kafein tidak berhubungan dengan kadar kalsium urin pada laki-laki dewasa awal

Kata Kunci: Kadar kalsium urin, asupan kafein, asupan fosfor, asupan protein, asupan kalsium, asupan natrium

\section{PENDAHULUAN}

Osteoporosis

didefinisikan sebagai penurunan massa tulang dan ditandai oleh meningkatnya risiko fraktur akibat kerapuhan tulang. Pencegahan terjadinya kepadatan tulang yang rendah dapat dilakukan dengan mengoptimalkan pembentukan massa tulang pada saat masa pertumbuhan yaitu usia 20-35 tahun. ${ }^{1}$ Penelitian mengenai osteoporosis di Jakarta Tahun 2011 pada subjek usia 20-25 tahun, menyatakan sebanyak 6,3\% mengalami osteoporosis dan 51,1\% mengalami osteopenia (pre-osteoporosis). ${ }^{2}$ Semarang merupakan ibukota Jawa Tengah dengan prevalensi osteopenia yang cukup tinggi pada Tahun 2009 yaitu sebesar 18,8\%. ${ }^{3}$

Salah satu faktor penyebab terjadinya osteoporosis yaitu tingginya pengeluaran kalsium dalam urin. ${ }^{4}$ Oleh karena itu pengeluaran kalsium urin dijadikan salah satu indikator untuk mengukur status kepadatan tulang, sebelum merujuk ke osteoporosis. Tingginya pengeluaran kalsium urin dipengaruhi oleh faktor yang tidak dapat dikendalikan dan faktor yang dapat dikendalikan. Faktor yang tidak dapat dikendalikan meliputi usia, jenis kelamin dan genetik. ${ }^{5,6}$ Sedangkan faktor yang dapat dikendalikan antara lain beberapa asupan zat 
gizi seperti natrium, protein, fosfor, kalsium dan kafein. ${ }^{7}$

Gaya hidup menjadi salah satu faktor penting terjadinya osteoporosis, salah satunya adalah konsumsi kafein. ${ }^{8}$ Penelitian menyebutkan asupan tinggi kafein dapat mempengaruhi pengeluaran kalsium urin bila asupan kalsium tidak tercukupi dari kebutuhan yang seharusnya. ${ }^{9}$ Menurut Riset Kesehatan Dasar Tahun 2013, perilaku konsumsi minuman berkafein $\geq 1$ kali sehari masyarakat Indonesia mencapai $31,5 \% .^{10}$ Penelitian lain menyebutkan pada subjek laki-laki dewasa awal kebiasaan konsumsi kopi yaitu 79,38\% mengkonsumsi kopi 1 cangkir, $17,53 \%$ mengkonsumsi kopi 2-3 cangkir, dan 3,09\% mengkonsumsi kopi $>3$ cangkir. ${ }^{11}$ Sementara itu menurut Institute of Medicine asupan kalsium orang Indonesia belum memenuhi kebutuhan yaitu hanya sekitar 25-30\% dari kebutuhan. Berdasarkan penelitian yang dilakukan di Tangerang, 59,2\% dewasa awal dalam kategori asupan kalsium yang kurang $\left(<80 \%\right.$ Angka Kebutuhan Gizi). ${ }^{2}$ Berdasarkan hal tersebut, apabila masyarakat khususnya dewasa awal banyak yang mengkonsumsi tinggi kafein dan diimbangi dengan asupan kalsium yang rendah maka akan menyebabkan tingginya pengeluaran kalsium urin.

Makanan yang mengandung kafein diantaranya kopi, teh, minuman berkarbonasi dan cokelat. Kopi robusta dan kopi arabika merupakan jenis kopi yang sering di konsumsi di Indonesia. Kopi robusta memiliki kandungan kafein yang lebih tinggi dibandingkan dengan kopi arabika yaitu $2 \%$ dari berat kopi sedangkan kopi arabika mengandung kafein $1 \%$ dari berat kopi. Kandungan tinggi kafein selanjutnya yaitu kopi instan dan teh sekitar 20-73 $\mathrm{mg} / 100 \mathrm{ml}$ dan minuman berkarbonasi yaitu 9-19 $\mathrm{mg} / 100 \mathrm{ml}$. Selain kopi, teh dan minuman berkarbonasi, cokelat juga merupakan sumber kafein. Sedangkan dalam 100 gr permen cokelat mengandung kafein sekitar 5-20 mg. ${ }^{12,13}$

Asupan tinggi kafein dapat meningkatkan pengeluaran kalsium urin melalui mekanisme penurunan reabsorbsi kalsium di ginjal sehingga menyebabkan keseimbangan kalsium menjadi negatif yang nantinya akan mempengaruhi kepadatan tulang. ${ }^{14.15}$ Asupan kafein $300-400$ mg dapat meningkatkan kalsium dalam urin sebesar $0.25 \mathrm{mmol}$ atau $10 \mathrm{mg}$ per hari melalui penurunan reabsorbsi ginjal. ${ }^{7}$ Penelitian menyebutkan bahwa asupan kafein yang terkandung di dalam $177,5 \mathrm{ml}$ kopi dapat meningkatkan pengeluaran kalsium melalui urin sebanyak $4,6 \mathrm{mg} /$ hari. ${ }^{16}$

Gaya hidup mengkonsumsi tinggi kafein terutama kopi banyak dilakukan oleh laki-laki yaitu sekitar 3,83 kg/tahun dibandingkan dengan wanita yaitu sebesar 1,97 kg/tahun. ${ }^{17}$ Asupan tinggi kafein dan diimbangi dengan rendahnya asupan kalsium pada usia dewasa awal akan berdampak negatif terhadap kalsium urin. Oleh karena itu, peneliti tertarik untuk meneliti mengenai hubungan asupan kafein dengan kalsium urin pada laki-laki dewasa awal.

\section{METODE}

Penelitian ini dilakukan di Jurusan Peternakan Universitas Diponegoro. Penelitian ini termasuk dalam kategori lingkup penelitian gizi masyarakat dan merupakan penelitian observasional dengan rancangan crossectional. Populasi terjangkau dalam penelitian ini yaitu mahasiswa usia 18-24 tahun di Jurusan Peternakan UNDIP Semarang yang datang pada saat pengambilan data. Sebanyak 46 mahasiswa terpilih menjadi subjek setelah melalui seleksi dari kriteria inklusi dan eksklusi. Kriteria inklusi meliputi mahasiswa usia 18-24 tahun di Jurusan Peternakan UNDIP Semarang, tidak memiliki riwayat penyakit asam urat, hipertensi, batu ginjal dan hiperparatiroid, tidak mengkonsumsi obat-obatan tertentu seperti diuretik tiazid, omeprazole, dan spironolankton, tidak mengkonsumsi minuman beralkohol serta bersedia menjadi sampel dalam penelitian ini. Sedangkan kriteria eksklusi yaitu mengundurkan diri untuk menjadi subjek penelitian dan berpuasa.

Menurut penghitungan besar sampel untuk rancangan crossectional dengan rumus korelasi, sampel minimal yang dibutuhkan yaitu sebesar 46 orang. Pengambilan sampel dilakukan dengan metode consecutive sampling yaitu sampel yang datang menjadi subjek apabila sesuai dengan kriteria inklusi dan sampai jumlah sampel minimal terpenuhi. Variabel bebas dalam penelitian ini yaitu asupan kafein, sedangkan variabel terikat yaitu kadar kalsium urin. Variabel perancu meliputi asupan protein, asupan fosfor, asupan kalsium, dan asupan natrium. Data asupan kafein, asupan protein, asupan fosfor, asupan kalsium, dan asupan natrium diperoleh melalui food recall 24 jam selama 4 hari berturut-turut. Data ini menjelaskan mengenai jumlah rerata asupan per hari selama 4 hari yang berasal dari makanan dan minuman. Hasil tersebut dikonversikan ke dalam gram untuk protein, serta milligram untuk kafein, fosfor, kalsium, dan natrium, kemudian hasilnya diolah menggunakan program nutrisurvey.

Kebutuhan asupan protein dihitung menggunakan rumus $1 \mathrm{~g} / \mathrm{kg} \mathrm{BB}$, kemudian untuk menghitung kecukupannya dengan 
membandingkan asupan protein dengan kebutuhan dikali $100 \%$. Apabila asupan protein memenuhi 80\%-100\% kebutuhan maka tergolong asupan protein cukup. Tergolong asupan kurang apabila $<80 \%$ dan tergolong lebih apabila $>100 \%$. Asupan kafein tergolong cukup apabila subjek mengkonsumsi 0-300 mg/hari dan tergolong asupan lebih apabila subjek mengkonsumsi $>300 \mathrm{mg} /$ hari. Asupan fosfor, asupan kalsium, dan asupan natrium dibandingkan dengan AKG, apabila asupan $<80 \%$ AKG maka dikategorikan dalam asupan kurang, apabila asupan antara 80-110\% AKG maka dikategorikan dalam asupan cukup, sedangkan apabila asupan $>110 \%$ AKG maka dikategorikan asupan lebih. ${ }^{18}$

Kadar kalsium urin diukur menggunakan metode ortho-cresolphtalein complexone (OCPC). Urin ditampung ke dalam tempat yang telah disediakan pihak klinik. Penampungan urin dilakukan pada jam 7 pagi sampai jam 7 pagi hari berikutnya (24 jam) pada hari ke 5 setelah pengambilan data recall $24 \mathrm{jam}$. Urin yang telah ditampung diletakkan di tempat yang tidak terkena sinar matahari. Kadar kalsium urin untuk laki-laki dewasa tergolong rendah apabila $<100 \mathrm{mg} / 24 \mathrm{jam}$, tergolong normal apabila kadarnya $100-275 \mathrm{mg} / 24$ jam dan tergolong tinggi apabila $>275 \mathrm{mg} / 24$ jam.

Analisis univariat dilakukan untuk mendiskripsikan karakteristik subjek penelitian yang terdiri dari asupan kafein, asupan protein, asupan fosfor, asupan kalsium, asupan natrium, serta kalsium urin subjek. Sebelum analisis bivariat, dilakukan normalitas data dengan Shapiro-Wilk. Analisis bivariat dilakukan untuk melihat hubungan variabel terikat (kalsium urin) dengan variabel bebas (asupan kafein). Uji korelasi Rank Spearman digunakan untuk menguji hubungan asupan kafein dengan kalsium urin, serta menguji hubungan asupan kalsium dengan kalsium urin karena data tidak berdistribusi normal. Sedangakan asupan protein, asupan fosfor, dan asupan natrium masingmasing diuji korelasi dengan variabel kalsium urin yaitu menggunakan uji korelasi Pearson Product Moment karena data berdistribusi normal.

\section{HASIL}

Tabel 1. Karakteristik kadar kalsium urin

\begin{tabular}{lll}
\hline Variabel & n & \% \\
\hline Kadar kalsium urin & & \\
Rendah & 22 & 47,8 \\
Normal & 23 & 50 \\
Tinggi & 1 & 2,2 \\
\hline
\end{tabular}

Tabel 2. Nilai minimum, maksimum, rerata, dan standar deviasi variabel

\begin{tabular}{llll}
\hline Variabel & Minimal & Maksimal & Rata-rata \pm SD \\
\hline Kalsium urin (mg/24 jam) & 56,0 & 353,0 & $116,02 \pm 50,02$ \\
Asupan kafein (mg) & 0 & 439,5 & $95,74 \pm 101,67$ \\
Tingkat asupan protein (\%) & 42,0 & 114,0 & $71 \pm 16,65$ \\
Tingkat asupan fosfor (\%) & 34,0 & 123,0 & $70,41 \pm 19,54$ \\
Tingkat asupan kalsium (\%) & 5,0 & 46,0 & $17,33 \pm 7,81$ \\
Tingkat asupan natrium (\%) & 26 & 124 & $74,19 \pm 22,31$ \\
\hline
\end{tabular}

Tabel 3. Distribusi frekuensi asupan kafein, tingkat asupan protein, tingkat asupan fosfor, tingkat asupan kalsium, tingkat asupan natrium dengan kadar kalsium urin

\begin{tabular}{llllll}
\hline \multirow{2}{*}{ Variabel } & \multicolumn{4}{c}{ Kadar kalsium urin } \\
\cline { 2 - 6 } Asupan kafein & Cukup & Rendah $\mathrm{n}(\%)$ & Normal $\mathrm{n}(\%)$ & Tinggi n $(\%)$ & Total $\mathrm{n}(\%)$ \\
\hline \multirow{3}{*}{ Tingkat asupan protein } & Lebih & 0 & $22(48,8 \%)$ & 0 & $44(95,7 \%)$ \\
& Kurang & $18(58 \%)$ & $13(41,9 \%)$ & 0 & $2(4,3 \%)$ \\
& Cukup & $2(18,2 \%)$ & $9(81,8 \%)$ & 0 & $31(67,4 \%)$ \\
& Lebih & $2(50 \%)$ & $1(25 \%)$ & $1(25 \%)$ & $11(23,9 \%)$ \\
\multirow{3}{*}{ Tingkat asupan fosfor } & Kurang & $16(51,6 \%)$ & $15(48,4 \%)$ & 0 & $31(57,4 \%)$ \\
& Cukup & $6(42,9 \%)$ & $7(50 \%)$ & $1(7,1 \%)$ & $14(30,4 \%)$ \\
& Lebih & 0 & $1(100 \%)$ & 0 & $1(2,2 \%)$ \\
\hline \multirow{3}{*}{ Tingkat asupan kalsium } & Kurang & $22(47,8 \%)$ & $23(50 \%)$ & $1(2,2 \%)$ & $46(100 \%)$ \\
& Cukup & 0 & 0 & 0 & 0 \\
& Lebih & 0 & 0 & 0 & 0 \\
\hline \multirow{2}{*}{ Tingkat asupan natrium } & Kurang & $12(46,2 \%)$ & $14(53,8 \%)$ & 0 & $26(56,5 \%)$ \\
& Cukup & $7(50 \%)$ & $6(42,9 \%)$ & $1(7,1 \%)$ & $14(30,4 \%)$ \\
& Lebih & $3(50 \%)$ & $3(50 \%)$ & 0 & $6(13,1 \%)$ \\
\hline
\end{tabular}


Subjek penelitian dalam penelitian ini adalah laki-laki dewasa awal usia 18-24 tahun sebanyak 46 subjek. Data karakteristik kadar kalsium urin subjek dapat dilihat pada Tabel 1.

Berdasarkan Tabel 1 subjek yang memiliki kadar kalsium urin rendah sebesar 22 subjek $(47,8 \%)$. Sedangkan subjek yang memiliki kadar kalsium urin tinggi hanya 1 subjek $(2,2 \%)$.

Berdasarkan Tabel 2 rata-rata kadar kalsium urin tergolong normal yaitu $116,02 \mathrm{mg} / 24$ jam dengan kadar maksimal dan minimal kalsium urin berkisar antara $353 \mathrm{mg} / 24 \mathrm{jam}$ dan $56 \mathrm{mg} / 24$ jam. Asupan kafein subjek maksimal 439,5 mg dan minimal $0 \mathrm{mg}$ dengan rata-rata $95,74 \mathrm{mg}$. Rata-rata tingkat asupan protein, tingkat asupan fosfor, tingkat asupan kalsium dan tingkat asupan natrium tergolong rendah yaitu $<80 \%$ kebutuhan menurut AKG.

Berdasarkan Tabel 3 dapat dilihat bahwa subjek yang memiliki asupan kafein dalam kategori lebih dengan kadar kalsium urin tinggi sebesar 50\%, sedangkan subjek yang memiliki asupan kafein dalam kategori lebih dengan kadar kalsium urin normal sebesar $50 \%$. Terdapat $25 \%$ subjek memiliki tingkat asupan protein lebih dengan kadar kalsium urin yang tinggi. Terdapat $7,1 \%$ subjek memiliki tingkat asupan fosfor yang cukup dengan kadar kalsium urin tinggi dan terdapat $100 \%$ subjek memiliki tingkat asupan fosfor lebih dengan kadar kalsium urin normal. Seluruh subjek memiliki tingkat asupan kalsium yang termasuk dalam kategori kurang.

Tabel 4. Hubungan asupan kafein, asupan protein, asupan fosfor, asupan kalsium dan asupan natrium dengan kalsium urin

\begin{tabular}{lcc}
\multicolumn{1}{c}{ Variabel } & \multicolumn{2}{c}{ Kadar kalsium urin } \\
\cline { 2 - 3 } & $\mathbf{r}$ & $\mathbf{p}$ \\
\hline Asupan kafein & 0,084 & $0,579^{*}$ \\
& & \\
Tingkat asupan protein & 0,420 & $0,004^{* *}$ \\
Tingkat asupan fosfor & 0,356 & $0,015^{* *}$ \\
Tingkat asupan kalsium & 0,233 & $0,119^{*}$ \\
Tingkat asupan natrium & 0,201 & $0,180^{* *}$ \\
*uji rank-Spearman & & \\
*uji Pearson Product Moment & &
\end{tabular}

Berdasarkan hasil uji korelasi rankSpearman, asupan kafein tidak memiliki hubungan bermakna dengan kalsium urin ( $\mathrm{p}$ $>0,05$ ). Arah korelasi positif menunjukkan bahwa semakin tinggi asupan kafein, maka semakin tinggi pula pengeluaran kalsium urin dan sebaliknya. Berdasarkan data tersebut, hanya asupan protein dan asupan fosfor yang memiliki hubungan bermakna dengan kalsium urin $(\mathrm{p}<0,05)$ dengan arah korelasi positif yang artinya semakin tinggi tingkat asupan protein maka semakin tinggi kalsium urin dikeluarkan dan sebaliknya, sama halnya untuk tingkat asupan fosfor, semakin tinggi tingkat asupan fosfor maka semakin tinggi pula kalsium urin dikeluarkan dan sebaliknya. Tingkat asupan protein memiliki $\mathrm{r}=0,420$ dan $\mathrm{p}=0,004$, sedangkan tingkat asupan fosfor memiliki $\mathrm{r}=0,356$ dan $\mathrm{p}=0,015$.

\section{PEMBAHASAN}

Hasil penelitian menunjukkan bahwa lakilaki dewasa awal yang memiliki kadar kalsium urin $>275$ (hiperkalsiuria) sebanyak 2,2\%, lebih sedikit dibandingkan dengan laki-laki dewasa awal yang memiliki kadar kalsium urin normal $(50 \%)$ dan yang memiliki kadar kalsium urin rendah $(47,8 \%)$. Hiperkalsiuria dipengaruhi oleh berbagai faktor diantaranya asupan, meliputi asupan protein, fosfor, natrium, kalsium dan kafein. ${ }^{7}$ Pada penelitian ini laki-laki dewasa awal yang mengkonsumsi tinggi kafein (>300 mg/hari) hanya 4,3\% dan seluruh lakilaki dewasa awal asupan kalsiumnya $<80 \%$ berdasarkan AKG. Sebagian besar sumber kafein yang dikonsumsi yaitu teh 1-2 gelas per hari dan kopi instan 1 gelas per hari. Konsumsi kafein dalam jumlah yang tinggi dan diimbangi dengan asupan kalsium yang kurang akan meningkatkan risiko pengeluaran kalsium urin dalam kadar yang berlebih melalui peningkatan absorbsi kalsium di usus dan penurunan reabsorbsi kalsium di ginjal sehingga menyebabkan keseimbangan kalsium menjadi negatif yang nantinya akan mempengaruhi kepadatan tulang. ${ }^{9,14,15}$

Menurut hasil uji korelasi, tidak ada hubungan asupan kafein dengan kadar kalsium urin. Hal tersebut terjadi karena data asupan kafein dan data kalsium urin yang didapatkan tidak berdistribusi normal, terdapat data yang terlalu tinggi dan terlalu rendah, sehingga mengakibatkan 
kedua variabel tersebut tidak berhubungan. Nilai terendah dan tertinggi untuk kadar kalsium urin dalam penelitian ini yaitu $56 \mathrm{mg} / 24$ jam dan 353 $\mathrm{mg} / 24$ jam, sedangkan nilai terendah dan tertinggi untuk asupan kafein berturut-turut yaitu $0 \mathrm{mg}$ dan $439,5 \mathrm{mg}$ dengan rata-rata $95,74 \mathrm{mg}$. Rata-rata asupan kafein dalam penelitian ini masih tergolong rendah untuk dapat mengeluarkan kalsium dalam urin dalam jumlah tinggi. Asupan tinggi kafein juga hanya dapat memiliki sedikit efek untuk dapat meningkatkan kalsium urin, sesuai dengan teori bahwa asupan kafein 300-400 mg hanya dapat meningkatkan kalsium dalam urin sebesar 0.25 mmol atau $10 \mathrm{mg}$ per hari melalui penurunan reabsorbsi ginjal. ${ }^{7}$

Berdasarkan hasil analisis terdapat satu orang laki-laki dewasa awal yang memiliki kadar kalsium urin normal (154 mg/24jam) dengan konsumsi kafein berlebih yaitu 339,5 mg, melalui asupan 1 gelas kopi hitam (8 gram kopi hitam) dan 1 gelas teh manis ( 5 gram teh biasa). Sedangkan asupan protein masih dalam kategori cukup, serta asupan kalsium dalam kategori rendah. Namun untuk asupan natrium laki-laki dewasa awal tersebut mengkonsumsi lebih dari AKG yaitu mencapai 1872 mg. Asupan tinggi natrium dapat menyebabkan natrium yang keluar bersama urin semakin tinggi pula, setiap peningkatan $100 \mathrm{mmol}$ (2300 mg) natrium urin maka akan diikuti peningkatan kalsium urin sekitar $1,1 \mathrm{mmol}(44 \mathrm{mg})$. Tingginya pengeluaran kalsium dalam urin karena asupan natrium yang berlebih terjadi melalui mekanisme peningkatan laju filtrasi glomerular dan penurunan reabsorbsi kalsium di tubulus distal. ${ }^{19}$

Disisi lain terdapat laki-laki dewasa awal yang memiliki kadar kalsium urin tinggi $353 \mathrm{mg} / 24$ jam dengan asupan kafein yang juga berlebih yaitu sebesar 439,5 mg. Asupan kafein tersebut bersumber dari 1 gelas kopi hitam (8 gram kopi hitam), 1 gelas kopi sachet, dan 1 gelas teh manis (5 gram teh biasa). Asupan protein tergolong berlebih, asupan fosfor tergolong kurang dan asupan natrium tergolong cukup. Asupan kafein yang berlebih dapat mempengaruhi pengeluaran kalsium urin yang tinggi melalui penurunan reabsorbsi kalsium di ginjal, sesuai dengan yang dialami laki-laki dewasa awal ini, asupan kafein 439,5 $\mathrm{mg}$ dapat mengeluarkan kalsium urin sebesar $353 \mathrm{mg} / 24 \mathrm{jam}$.

Asupan protein yang berlebih akan meningkatkan pengeluaran kalsium urin karena keseimbangan asam basa. Asupan tinggi protein, terutama protein hewani mengandung sulfur yang berasal dari asam amino yang akan menciptakan kondisi asam di dalam tubuh. Hal ini akan menyebabkan kalsium lebih banyak dikeluarkan untuk menetralkan kondisi asam tersebut, akibatnya kalsium yang keluar bersama urin meningkat. ${ }^{18}$ Sesuai dengan penelitian yang menyebutkan bahwa setiap peningkatan $50 \mathrm{~g}$ asupan protein dapat meningkatkan pengeluaran kalsium dalam urin sebanyak $1,6 \mathrm{mmol}(6,4 \mathrm{mg}) .{ }^{19}$

Asupan fosfor berperan penting terhadap keseimbangan kalsium di dalam tubuh. Berdasarkan hasil penelitian, asupan fosfor berhubungan secara signifikan dengan kalsium urin. Kelebihan asupan fosfor meningkatkan jumlah fosfor dalam serum dan menggangu pengaturan hormone kalsium sehingga dapat menurunkan kekuatan tulang dan meningkatkan risiko terjadinya fraktur. Asupan tinggi fosfor diimbangi dengan asupan kalsium yang rendah dapat menyebabkan penurunan absorbsi kalsium dan serum kalsium menurun, sehingga akan menstimulasi sekresi hormone paratiroid untuk menjaga homeostasis dengan meresorpsi kalsium dari tulang menuju darah. Namun apabila hal tersebut terjadi terus menerus dalam jangka waktu yang lama akan menyebabkan deposit kalsium di tulang menurun sehingga dapat berpengaruh negative terhadap kesehatan tulang. ${ }^{20}$

\section{SIMPULAN}

Terdapat 1 subjek $(2,2 \%)$ memiliki kadar kalsium urin tinggi dan 22 subjek (47,8\%) memiliki kadar kalsium urin rendah. Sebanyak 2 subjek $(4,35 \%)$ memiliki asupan kafein berlebih, namun rerata asupan kafein cenderung rendah yaitu 95,74 mg. Menurut analisis, asupan kafein, asupan kalsium, dan asupan natrium tidak berhubungan dengan kalsium urin, sedangkan asupan protein dan asupan fosfor memiliki hubungan yang signifikan dengan kalsium urin.

\section{SARAN}

Saran untuk subjek penelitian, perlu membatasi asupan kafein sampai dalam jumlah yang diperbolehkan serta mengkonsumsi sumber protein, sumber fosfor dan sumber kalsium sesuai dengan kebutuhan masing-masing. Hal tersebut dilakukan agar kalsium yang keluar bersama urin tidak meningkat. Saran untuk penelitian selanjutnya yaitu perlu dilakukan penelitian lebih lanjut mengenai hubungan asupan kafein dengan kalsium urin menggunakan metode kohort, karena dilaksanakan secara continue dan longitudinal, sehingga dapat menerangkan hubungan antar faktor-faktor risiko dengan efek secara lebih jelas. 


\section{DAFTAR PUSTAKA}

1. Rubenstein David, David Wayne, dan John Bradley. Lecture Notes: Kedokteran Klinis. 2007. P 200. PT Gelora Aksara Pratama.

2. Permatasari Tria Astika Endah. Hubungan Asupan Kalsium dan Faktor Risiko Lainnya Dengan Kejadian Osteoporosis Pada Kelompok Dewasa Awal di Wilayah Ciputat-Tangerang Selatan. Jurnal Kedokteran dan Kesehatan. 2011;7(2).

3. Wulandari Meikawati. Faktor Yang Berhubungan dengan Kepadatan Tulang Remaja. Program Pasca Sarjana Universitas Diponegoro.2009:1-10.

4. Giuseppe Vezzoli, Laura Soldati, Teresa Arcidiacono. Urinary calcium is a determinant of bone mineral density in elderly men participating in the In CHIANTI study. Kidney International. 2005; 67: 2006-2014.

5. Robert D. Lee. Musculoskeletal System. In: Maria Nelmis And Kathryn P. Suchr, editors. Nutrition Theraphy And Pathophsiology $2^{\text {nd }}$ Ed. USA : Wadsworth 2011. p 771-787;25.

6. Kerstetter JE, O'Brien KO, Insogna KL. Low protein intake: The impact on calcium and bone homeostasis in humans. J Nutr. 2003;133(3):855861.

7. Gropper, S. S., Smith, J. L. \& Groff, J. L. Advanced Nutrition and Human

Metabolism. Cengage Learning: Wadsworth. 2009; 431439.

8. Hallstrom Helena, Hakan Melhus, Anders Glynn, Lars Lind, Ann-Christine Syvanen, Karl Michaelsson. Coffee consumption and CYP1A2 genotype in relation to bone mineral density of the proximal femur in elderly men and women: a cohort study. Nutrition \& Metabolism. 2010; 7-12.

9. Yang-Hwei Tsuang, Jui-Sheng Sun, Li-Ting Chen, Samuel Chung-Kai Sun and San-Chi Chen. Direct effects of caffeine on osteoblastic cells metabolism: the possible causal effect of caffeine on the formation of osteoporosis. journal of Orthopaedic Surgery and Research. 2006; 1:7.

10. Departemen Kesehatan Ri. Riset Kesehatan Dasar Tahun 2013. Available At http:gizi.depkes.go.id/resources/download/RISKE SDAS2013.Pdf.

11. Purdiani Monica. Hubungan Penggunaan Minuman Berkafein terhadap Pola Tidur dan Pengaruhnya pada Tingkah Laku Mahasiswa/I Universitas Surabaya. 2014;3(1).

12. Nawrot P, S. Jordan, J. Eastwood, J. Rotstein, A. Hugenholtz and M. Feeley Effects of caffeine on human health. Food Additives and Contaminants. 2003;20(1): 1-30.

13. Butt M. S., A. Ahmed, M.T. Sultan A. Imran, M. Yasin and M. Imran. Evaluating the effect of decaffeination on nutritional and antioxidant status of different coffee brands. Internet Journal of Food Safety. 2011;13:198-207.

14. Thompson Janice L, Melinda M. Manore, and Linda A. Vaughan. The Science of Nutrition.
United States of America: Pearson Education, Inc. 2011;415-513.

15. Massey LK, Whiting SJ. Caffeine, urinary calcium, calcium metabolism and bone. J Nutr 1993; 123:1611-4

16. M. J. Barger-Lux and R. P. Heaney. Caffeine and the calcium economy revisited. Osteoporosis International Journal. 1995;5(2): 97-102.

17. Lestari Endang Wiji. Tingkat Konsumsi Kopi Domestik Dan Faktor - Faktor Yang Mempengaruhi Pada Masyarakat Perkotaan Di Kabupaten Jember [Tesis]. Jawa Timur: Universitas Negeri Jember. 2012.

18. Gibson. S Rosalind. Principles of Nutrition Assesment second edition. 2005. United States of America: Oxford University Press Jennifer L. Bedford and Susan I. Barr. Higher Urinary Sodium, a Proxy for Intake, Is Associated with Increased Calcium Excretion and Lower Hip Bone Density in Healthy Young Women with Lower Calcium Intakes. Nutrients. 2011;3: 951-961.

19. Jennifer L. Bedford and Susan I. Barr. Higher Urinary Sodium, a Proxy for Intake, Is Associated with Increased Calcium Excretion and Lower Hip Bone Density in Healthy Young Women with Lower Calcium Intakes. Nutrients. 2011;3: 951961.

20. Takeda Eiji, Hironori Yamamoto, Hisami Yamanaka-Okumura, and Yutaka Taketani. Increasing Dietary Phosphorus Intake from Food Additives: Potential for Negative Impact on Bone Health. Adv. Nutr. 2014; 5: 92-97.

21. Özkaya Ozan, Necla Buyan, Ýlknur Erol, Yýldýz Atalay, Ufuk Beyazova, Figen Pahin. et al. The relationship between urinary calcium, sodium, and potassium excretion in full-term healthy newborns. The Turkish Journal of Pediatrics. 2005; 47: 39-45. 